Printed in Great Britain

\title{
SOME OBSERVATIONS UPON THE PERIPHERAL NERVOUS SYSTEM OF THE HAGFISH, MYXINE GLUTINOSA
}

\author{
By QUenTIN Bone
}

The Plymouth Laboratory

(Plate I and Text-figs. I-6)

The peripheral nervous system of the hagfish (Myxine glutinosa L.) has received little attention from histologists; indeed, since Retzius (I890, I892) published brief observations upon the occurrence of subcutaneous neurons, and upon the innervation of the striated muscles, the only work upon the histology of the system has been the description of the innervation of the gut by Brandt (I922), and of the gall bladder by Fänge \& Johnels (1959). The present paper describes observations made upon the innervation of the striated muscles; upon the subcutaneous neurons; and upon the innervation of the slime-apparatus.

\section{MATERIALS AND METHODS}

Initial observations were made upon small (5-7 in.) hagfish kindly fixed for me at Kristineberg zoological station by Dr D. B. Carlisle; all were fixed in David's (1955) methyl alcohol/acetic acid/formol fluid which gives good results with cyclostomes. Most of this material was embedded in polyester wax (Steedman, 1957), cut in various planes at 25-30 $\mu$, and impregnated by Palmgren's original method (Palmgren, 1948). Best results with these thick sections were obtained by diluting the reducer in the manner recommended for whole mounts (Palmgren, I95I). At a later date, living hagfish were sent by air from Kristineberg, and were used at Plymouth mainly for supra-vital methylene blue staining.

Portions of the animal were pinned out on wax plates, and floated in finger bowls of diluted methylene blue solution in sea water. This method gave better results than staining in a damp chamber. More concentrated solutions were sometimes injected under the skin, and into the deeper-lying parts of the pinned-out preparation. Fixation overnight in ammonium molybdate (10\%) was followed by washing in running tapwater for several hours, and rapid dehydration in ethanol. 
THE MOTOR INNERVATION OF STRIATED MUSCLE

The greater part of my observations upon the innervation of the striated muscles of the body was made upon the musculature of the ventral part of the body, whose organization is seen in Text-figs. I and 2.

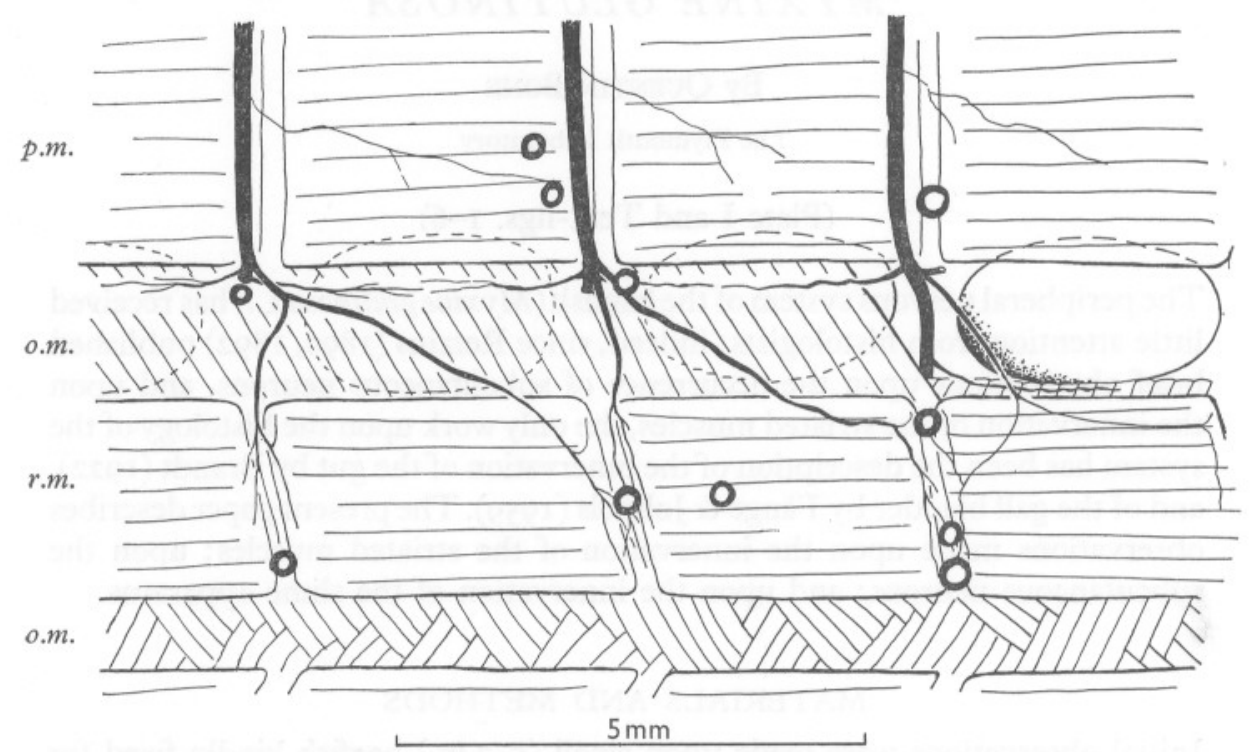

Text-fig. I. The ventral musculature of the gill region, to show the organization of the different muscles and the position of the sensory endings $(\mathbf{O})$ observable in a single methylene blue whole-mount preparation of the region. p.m.: parietal muscle; o.m. : oblique muscle; r.m.: rectus muscle.

The muscle sheets in this region are thinner than elsewhere in the body, and whole-mount preparations easier to examine, but conditions elsewhere are essentially the same. The anatomical organization of the muscles in Myxine has been admirably described by Cole (1907). It is only necessary to point out here that the oblique muscles (which run slanting backward from their upper limit external to the parietal muscles down to the mid-ventral line) differ in their arrangement in different regions of the body. In the gill region (which is illustrated) the oblique muscles cross the mid-ventral line and terminate against the medial border of the row of slime glands. In order to reach this point, they interdigitate in the mid-line in the striking manner shown. Farther back, in the trunk region, the fibres of the oblique muscles of either side abut in the mid-line and do not cross over to the opposite side. In both cases, the muscle is divided into two sets of fibres, the two joining at the level of the top of the slime glands, beside the bottom of the parietal muscle. Internally to the oblique muscle lie the paired longitudinal recti muscles, which pass along the floor of the coelomic cavity, and are subdivided into 
units more or less corresponding to the myotomal segmentation. Both the oblique and recti muscles and the parietal or myotomal muscles are innervated by mixed spinal nerves which, as will be seen below, contain fibres of at least five different types. As the spinal nerve passes down the inner surface of the parietal muscle, it sends fibres into the muscle, finally reaching its most ventral point. Here, rami are given off to the recti muscles and to the internal and external portions of the oblique muscle, whilst the main nerve bundle

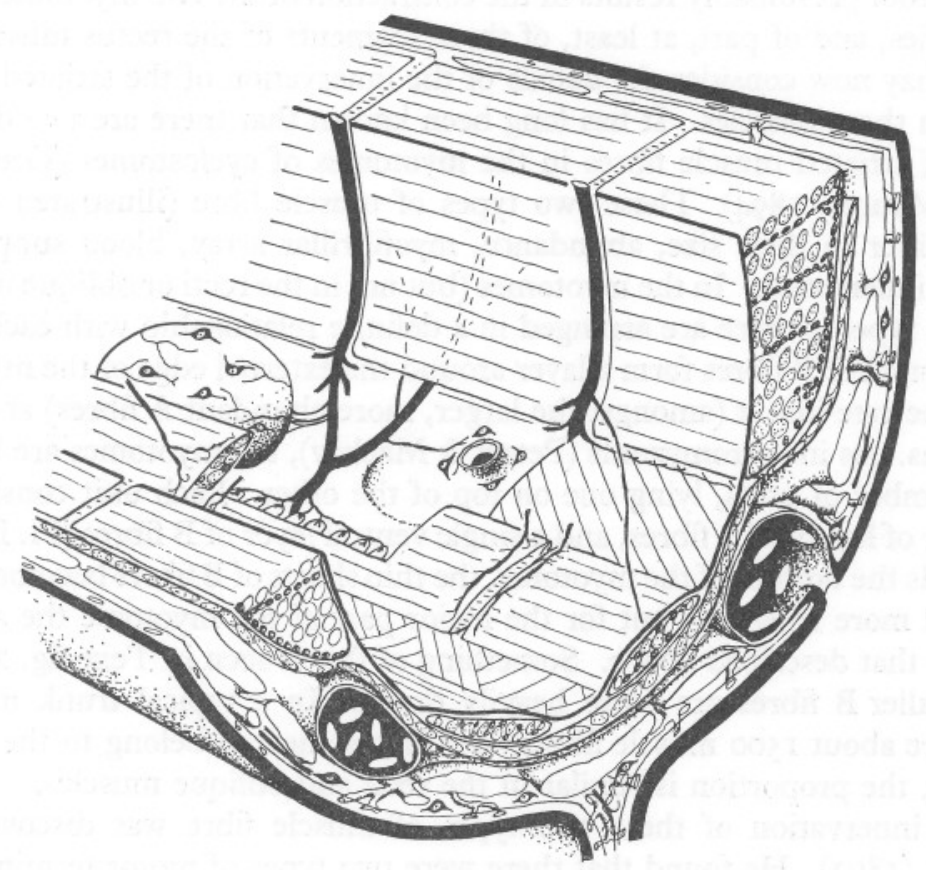

Text-fig. 2. Oblique view of the structure of the ventral part of the body in the gill region. On the right the orifice of a slime gland has been cut through, and the rectus and oblique muscles partially dissected to show the rami of the ventral spinal nerve. The smaller B-type muscle fibres are drawn more heavily than the larger A-type fibres, their arrangement in the parietal muscle is seen on the right of the figure.

turns directly downward, penetrating between the internal and external divisions of the oblique muscle. When it reaches the level of the outer surface of the oblique muscle, further rami are given off to the slime glands and to the internal portion of the oblique, and the nerve bundle then divides into a dorsal and a ventral branch, supplying the skin of the ventral and lateral parts of the animal. These relations are seen in Text-figs. I and 2.

Text-fig. I shows that whilst the arrangement in each segment is the same, the innervation of the approximately segmental divisions of the recti muscles overlaps between one sub-unit and another. That is to say, the segment of the 
rectus muscle supplied by the rami from one spinal nerve is also supplied by axons running in the rami of the two adjacent spinal nerves. A similar condition is found in the parietal muscles, as will be described below, and it seems that the overlap of innervation between segments (also found in petromyzonts, see Peters \& Mackay, 196I), reflected in the absence of strict segmentation in the motoneurons of the cord, must imply that the animal is unable to contract the muscles of one segment at a time; stimulation of one ventral root presumably results in the contraction of the two myotomes which it supplies, and of part, at least, of three segments of the rectus muscle.

We may now consider the details of the innervation of the striated muscle fibres in these muscles. It has long been known that there are two different types of striated muscle fibres in the myotomes of cyclostomes (Grenacher, I867; Maurer, 1894). These two types of muscle fibre (illustrated well by Cole) differ in their size, abundance, myofibrillar array, blood supply, and in their innervation. In the myotomes (but not in the recti or oblique muscles) the two types of fibre are arranged in a definite relationship with each other, for the smaller B fibres form a layer around the external edge of the myotome, and penetrate into it (amongst the larger, more abundant A fibres) at definite positions. As in petromyzonts (Peters \& Mackay), the myotomes are built up of a number of units, lying one on top of the other. Each unit consists of a number of layers of A fibres, and a single ventral layer of B fibres (Pl. I, fig. I). Towards the bottom of the myotome, the thin sheets of $\mathrm{B}$ fibres become broken up, and more irregular, but for the major part of the myotome the arrangement is that described above. Something of this is seen in Text-fig. 2, where the smaller B fibres are more heavily drawn. In a typical trunk myotome there are about 1500 muscle fibres, of which some 150 belong to the smaller B type; the proportion is similar in the recti and oblique muscles.

The innervation of these two types of muscle fibre was discovered by Retzius (1892). He found that there were two types of motor termination in the parietal muscles, the one consisting of large basket-like end-formations (Pl. I, fig. 2) upon the ends of the muscle fibres near the myosepta, and the other of fine fibres passing longitudinally along the muscle fibres, often beaded along their course. This latter ending Retzius found sometimes in the main body of the muscle, but it was most frequent at the outer edge of the myotome, and although Retzius does not explicitly state the fact, there can be no doubt that he observed the basket-like terminations upon the larger A fibres, and the longitudinal endings upon the B fibres. Retzius gives a good illustration of this pattern of innervation, but it is worth noting that it is in some respects somewhat diagrammatic, and contains one important error. At two points, he figured an axon branching to give on the one hand a basket-like endformation, and on the other a longitudinal ending. This was an oversight, for, as indeed we should expect, the two types of ending upon the two types of muscle fibre are invariably supplied by two different sorts of axon. The 
longitudinal endings of the B fibres are derived from axons of small diameter, whilst the basket-like endings of the A fibres are derived from axons of much greater diameter. The arrangement is seen in Text-fig. 3 .

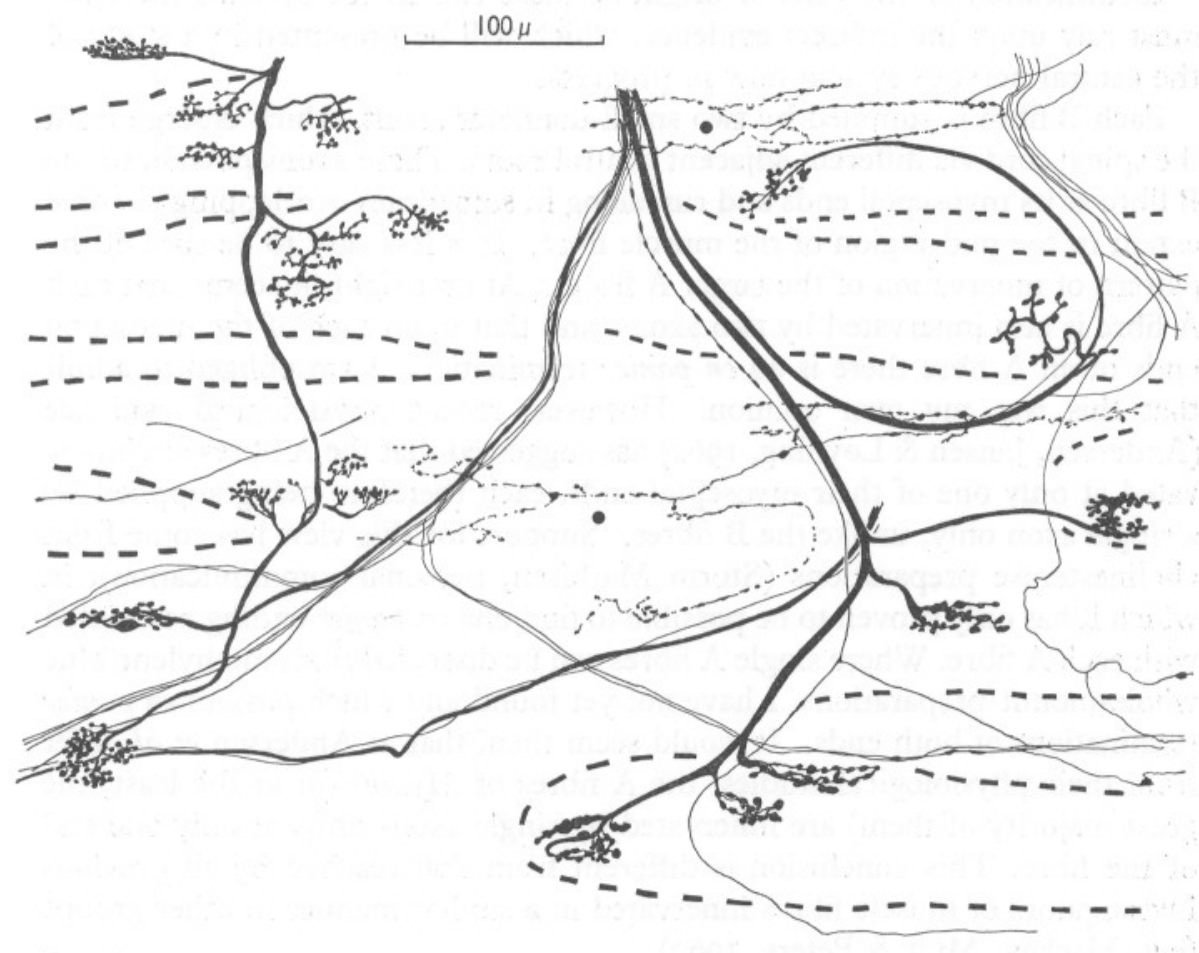

Text-fig. 3. A part of the innervation of the rectus muscle, drawn from a methylene blue whole-mount preparation. The septum dividing the two adjacent units of the muscle passes downwards about the middle of the diagram; the medial border of the muscle lies at the bottom of the figure. Two sensory endings ( ) are seen, and the arrangement of the large and small axon systems to the muscle fibres can be seen. The diagram represents an actual preparation; some end-formations and axons are undoubtedly unstained; the boundaries of the muscle fibres (indicated by heavy dashed lines) are not always visible.

Each axon supplies a number of muscle fibres, and a single axon may supply the muscle fibres belonging to two adjacent segments. There are in the trunk region about I60 axons visible with the light microscope in each ventral root, and if we assume that all of these are somatic-motor (in petromyzonts Johnels, 1956, has shown that a few viscero-motor axons emerge from ventral roots), then it appears that each axon must supply at least Io muscle fibres.

Since at the periphery the B fibres are supplied by axons of small diameter, and the A fibres by much larger axons (Text-fig. 3), it might be supposed that these axons could be traced into the cord through the ventral roots to their respective cells of origin. Unfortunately, however, the somatic-motor axons 
of cyclostomes vary in diameter along their course in a most remarkable manner (Johnston, I908), and at their exit from the ventral root they do not differ strikingly in diameter.

Identification of the cells of origin of these two motor systems therefore must rely upon the indirect evidence, which will be presented in a study of the central nervous system now in progress.

Each B fibre is supplied by two small-diameter axons, which emerge from the spinal cord via different adjacent ventral roots. These axons pass on to the B fibre at its myoseptal ends and run along it, sometimes overlapping to some extent in the mid-region of the muscle fibre. It is less easy to be sure of the pattern of innervation of the larger A fibres. At first sight, it seems that each A fibre is also innervated by two axons, and that upon each of the myoseptal ends of an A fibre there is an en panier termination. I am obliged to admit that this was my own opinion. However, recent physiological evidence (Andersen, Jansen \& Løyning, 1962) has suggested that the A fibres are innervated at only one of their myoseptal ends, each therefore being supplied by a single axon only, unlike the B fibres. Support for this view has come from cholinesterase preparations (Storm Mathisen, personal communication), in which it has only proven to be possible to find one $e n$ panier ending associated with each A fibre. Where single A fibres can be dissected from methylene blue whole-mount preparations, I have not yet found any which possess en panier terminations at both ends. It would seem then, that as Andersen $e t$ al. infer from their physiological studies, the A fibres of Myxine (or at the least, the great majority of them) are innervated by single axons only, at only one end of the fibre. This conclusion is different from that reached by all previous investigators of muscle fibres innervated in a similar manner in other groups (e.g. Mackay, Muir \& Peters, I960).

It seems hardly probable that the A fibres of Myxine would differ in their mode of innervation in such a fundamental respect from the similar muscle fibres of elasmobranchs, teleosts, dipnoans and Polypterus (all of which possess en panier terminations at the myoseptal ends of the larger fibres); the innervation of the muscle fibres of these groups deserves further investigation. The problems raised by the single or dual innervation of A-type muscle fibres in the various lower chordate groups are considered elsewhere (Bone, I963).

Some other striated muscles in Myxine are rather different from the parietal, recti, and oblique muscles. There are muscles (such as the muscle of the caudal heart) which consist only of B fibres. Other muscles contain only A fibres, and in some of these it is of particular interest that the end-formations, although of the general en panier type, are found only at the mid-point of the muscle fibre, and not at its ends. Cole's m. copulo-glossus profundis is innervated in this manner, and Retzius figured an end-formation at this site from a muscle 'at the base of the skull'. As in the parietal muscles, a single axon innervates several muscle fibres. 
The motor innervation of striated muscle in Myxine is rather similar to that described for petromyzonts by Peters \& Mackay (who do not describe the A fibre en panier terminations in any detail). In Petromyzon marinus L. there are large end-formations of the same general type as those found in Myxine (Text-fig. 4), but much larger and more extensive. Presumably these are upon the larger A fibres, but the arrangement does not seem to be exactly similar to that described by Peters \& Mackay in the smaller Lampetra, although the two genera both have a similar muscle-unit system in their myotomes (Grenacher). In adult $L$. planeri special arrangements are found along the inner surface of the muscle units, where the large plate-like A fibres are innervated by twigs from large-diameter axons.

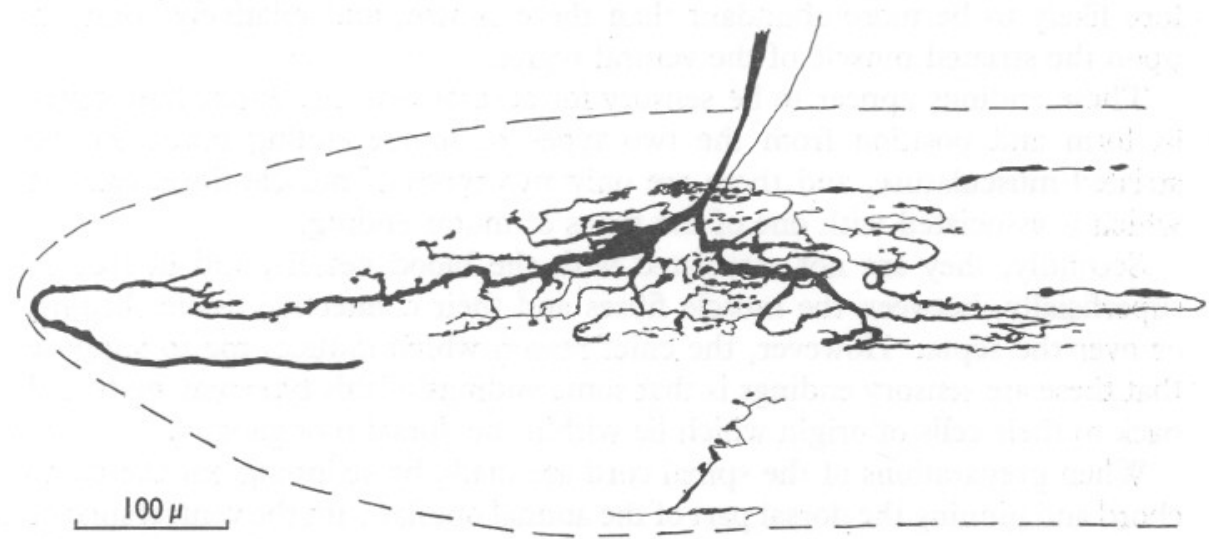

Text-fig. 4. The innervation of one end of a muscle unit in Petromyzon marinus, seen in lateral view. The smaller axon probably supplies the smaller B-type muscle fibres, the methylene blue preparation from which the figure was drawn was incompletely stained and the remainder of the fine-fibre motor system is not visible. The myoseptum is to the left. Compare the dimensions of this end-formation with those in Myxine (Pl. I, fig. 2).

Further investigations are evidently required before any detailed comparisons may be made between conditions in Myxine and in the different petromyzonts. In both groups, very little is understood of the significance of the presence of two motor systems within the myotomes, or of the functional implications of the curious muscle-unit arrangement found in the myotomal muscles. Cole supposed that the B fibres of Myxine were concerned with rapid contractions and the A fibres with sluggish ones, but Jansen \& Andersen (1960) and Andersen et al. have recently investigated the system physiologically and come to the reverse conclusion, which the histology of the innervation of the two types of fibre would seem to support. 


\section{THE SENSORY INNERVATION OF STRIATED MUSCLES}

In addition to the two types of motor terminations described above which are found upon the striated muscles of the hagfish, there are also other endings which evidently belong to a third category. These endings, which lie just under the connective tissue sheath of the muscle, usually over the septa between two sets of muscle fibres (Text-fig. I), are simple branching endings (Textfig. 3), varying somewhat in form but typically like those illustrated. The endings seen in the whole mount represented diagrammatically in Text-fig. I are probably only a part of the endings of this type actually present in the preparation, which was not equally fully stained throughout. They are therefore likely to be more abundant than there shown, and relatively common upon the striated muscle of the ventral region.

These endings appear to be sensory for several reasons. First, they differ in form and position from the two types of motor ending found in the striated musculature, and there are only two types of muscle fibre, each of which is associated with one of the types of motor ending.

Secondly, they are not associated with the blood vessels, and in fact lie superficially, between the muscle fibres and their connective tissue sheaths, or over the septa. However, the chief reason which induces me to suppose that these are sensory endings is that some endings of this type may be traced back to their cells of origin which lie within the dorsal root ganglia.

When preparations of the spinal cord are made by stripping out the notochord and pinning the dorsal part of the animal out flat with the ventral surface of the cord uppermost (Kolmer, I905), the nerve roots and spinal ganglia stain well. In most such preparations, where the staining has been successful, at each dorsal root ganglion there are one or rarely two cell bodies whose peripheral processes do not pass outward (ventrally) with the main bundle to join the ventral root axons, but pass more or less laterally, to end in a ramifying ending similar to those of the recti muscles (Text-fig. 5; Plate I, fig. 3). These endings lie between the notochordal sheath and the inner surface of the parietal musculature, just under the connective tissue sheath of the latter. There can be little doubt that this is a sensory ending; indeed it much resembles the simple sensory endings found in higher forms (e.g. in the pericardium, Dogiel, I898).

Since it is so similar to those of the ventral musculature, we may reasonably suppose that those also are sensory endings. From their position we may assume that they are deformed by the contractions of the muscle over which they lie, hence that they are proprioceptive in function.

Proprioceptive endings have been reported previously from myxinoids, for Allen (I9I7) described muscle spindles in the caudal heart muscle of Polistotrema, but Barker (personal communication) and I have made special search for these spindles without result, and it is very probable that what 
Allen actually saw in his preparations were small blood vessels. He did not use specific techniques for nerve fibres.

Muscle spindles are first found in the Amphibia, and in those forms without them (the cyclostome, elasmobranch, and teleost fish) little or nothing is known of the existence of proprioceptive endings.

In elasmobranchs, proprioceptive terminations have been identified histologically (Poloumordwinoff, I898; Cavalié, I902; Barets, 1956) and have been demonstrated electrophysiologically (Fessard \& Sand, 1937). These endings were found in the fins of Raja and in Torpedo. Fessard and Sand showed that they must also be present in the dogfish, where Barets later

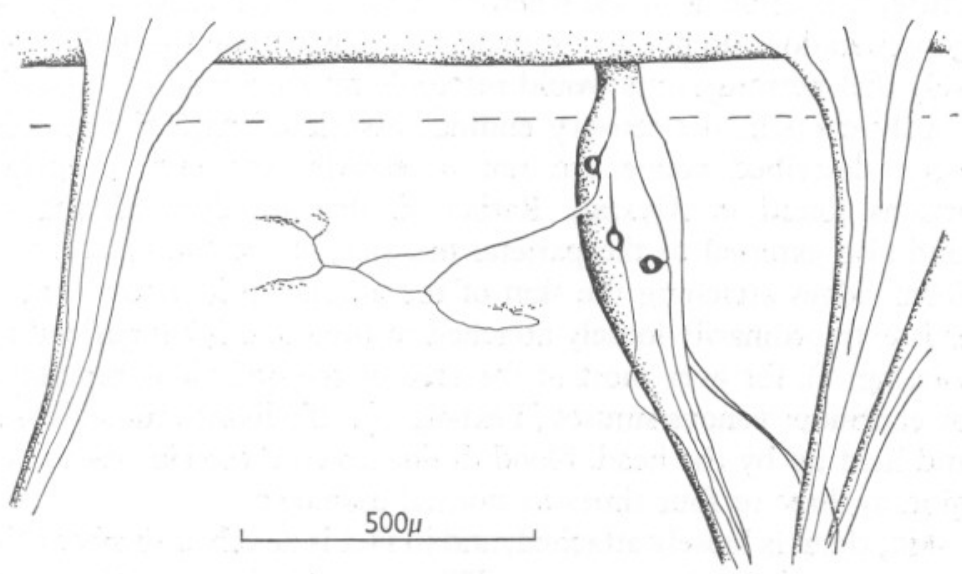

Text-fig. 5. The position of the sensory ending (Pl. I, fig. 3) on the inner surface of the parietal muscles near the cord. The cord runs across the top of the diagram, and ventral roots emerge on either side of the dorsal root in the middle. Drawn from a methylene blue whole mount of the cord viewed from the ventral surface.

found them in the fins (personal communication), and where Prof. J. E. Harris (personal communication) and I have observed them. They consist of elongate branches lying parallel with one another between the muscle fibres, bearing enlargements along their course recalling those found in the sensory endings of the laryngeal muscles of higher forms (Martino, 1958, fig. 9) and, on a different scale, those of the frog muscle spindle recently studied with the electron microscope by Katz (I96I).

Perhaps the beaded appearance of the simpler endings in Myxine reflects a normal feature of the ending, which would then resemble these other types of simple sensory ending, but this is impossible to say at present since I have only been able to observe them in Myxine with methylene blue which might give rise to the beaded appearance.

In teleosts, proprioceptive terminations have never been observed histologically or demonstrated electrophysiologically. None were observed by 
Barets (196I) in his admirable description of the motor innervation of the tench (Tinca) and the catfish (Ameirus); the earlier views (Giacomini, I898), that the basket-like endings were sensory, have now been shown to be erroneous, although held by Barker (1958).

It may perhaps be suggested that the endings of the muscles of Myxine represent the simplest stage in the development of proprioceptive endings in the vertebrates. If similar endings occur in teleost fishes, it is not very surprising that they have not been observed, for only in such favourable material as Myxine is it easy to see that they fall into a different class from the two types of motor ending. Even in petromyzonts, where pigment cells obscure the picture, it is difficult to see whether or not such endings are present; as yet, my preparations do not give sufficient evidence upon this point, although it is likely that petromyzonts would resemble myxinoids in this respect.

Curiously enough, the sensory endings associated with the muscles that have been described above are not necessarily the only proprioceptive terminations found in Myxine. Rather similar loosely ramifying endings are found also external to the parietal muscles, above the myosepta, where these form ridges attaching the skin of the animal to its body. The skin of Myxine is extraordinarily loosely attached to the underlying parietal muscles (see Cole, fig. I), for over most of the area of the body it is separated from them by enormous venous sinuses (Text-fig. 2). If a living animal is anaesthetized and held up by the head, blood drains down these sinuses to swell the tail region to three or four times its normal diameter.

The skin, then, is loosely attached, and in fact is attached firmly at the sides of the body only above the myosepta. When the skin is removed these appear on the surface of the parietal muscle as long hillocks. After subcutaneous injection of methylene blue into the anaesthetized animal, sensory endings stain within these hillocks (Text-fig. 6). Some of these fibres are passing to the skin, but some seem to end in the connective tissue of the external part of the myoseptum. Evidently such endings will be deformed by the bending of the body as the animal swims, and could afford proprioceptive information to the animal. It is true that after removal of the skin, the animals still exhibit co-ordinated swimming movements (Andersen, personal communication), but the endings remain in the myoseptal surface after removal of the skin. Physiological investigation is required before these questions may be settled. Histologically, it is possible that the myoseptal endings may be proprioceptive, and it is probable that the endings associated with the striated muscles are proprioceptive. It would be a relatively easy matter to record from the spinal nerves to test these hypotheses.

Very few experiments have been performed upon cyclostomes to elucidate the neurological basis of their swimming movements, and, as with teleost fisnes, it is an open question whether or not afferent information is required for the regulation of the swimming pattern. A good review of this contro- 
versy has been given by Healey (1957); it is interesting to note that the evidence for the importance of afferent regulation has come from experiments upon elasmobranchs (Lissman, 1946a,b), where it is known that there are proprioceptors in the muscles, and that Ten Cate (1935) found that Petromyzon spinal preparations had to receive stimuli from anterior regions or from outside the animal (proprioceptive information?) in order to maintain their activity.

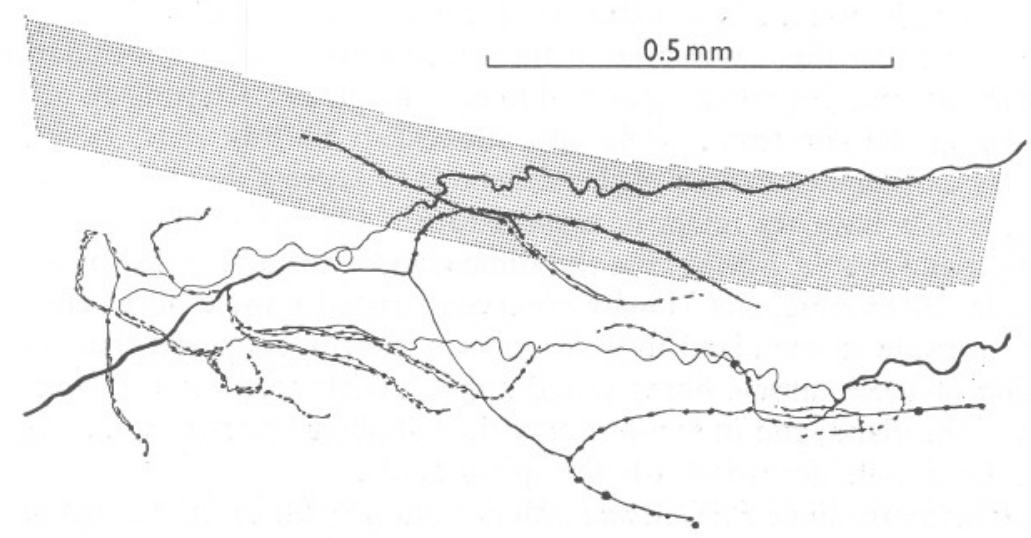

Text-fig. 6. The sensory endings associated with the external edge of the myoseptum. Drawn from a methylene-blue preparation of the outer surface of the parietal muscles after removal of the skin. The stippled area represents the position of the myoseptum, the endings (and the external edge of the myoseptum) have been displaced from above it during the flattening of the preparation.

\section{THE INNERVATION OF THE SLIME GLANDS AND THE SUBCUTANEOUS PLEXUS}

We may consider the innervation of the slime glands-which are to be regarded as simple invaginations of the skin (Blomfield, I882) - as a specialized part of the general subcutaneous innervation discovered by Retzius (I890), and so it is simpler to consider the innervation of the two regions together.

Hagfish produce a remarkable quantity of tenacious slime when suitably stimulated. In nature this propensity presumably serves to defend the animal from attacks by predators, and perhaps to suffocate the fish upon which the animal feeds. The slime is secreted from a double row of slime glands found in the ventral part of each segment from the head to behind the cloaca. In the living animal, the glands are whitish in appearance, and their openings (Text-fig. 2) are visible as small slits along the bottom of the parietal muscles. The slime is produced from remarkable cells (Blomfield, I882; Newby, I946) which when extruded into the water uncoil a thread several centimetres long. When such threads from many cells are uncoiled a very viscous slime is produced which it is difficult to remove from the animal or from the hands. Adam 
(I960) has found that hagfish show especial patterns of movement which seem to be related to the escape from this secreted slime.

The production of slime takes place when the animal is more or less strongly stimulated: 'intense excitement in most cases leads to the production of large amounts of slime' (Adam). Ferry (I94I) has found that electrical stimulation leads to the production of slime in Polistotrema. It seems probable therefore that the process is under the control of the nervous system, but exactly how this control is exerted is a matter of dispute. On the one hand, Blomfield pointed out that the contraction of the oblique muscles (which underlie the slime glands, see diagram 2) appeared to be 'capable of exercising an influence in ejecting the contents'. Cole also subscribed to this view, stating that 'another important function of the obliquus is to express the pre-cloacal slime sacks, which have no intrinsic musculature'. On the other hand, Müller (1836) found that in Bdellostoma the slime glands are surrounded by a special muscular membrane, and Newby observed striated muscle fibres embedded in the capsule of the gland in Polistotrema. Newby supposed that the contraction of these muscle fibres would apply a fairly uniform pressure on all parts of the gland, and in sections near the tail observed 'nerves... extending from the muscle fibres towards the spinal cord'.

Furthermore, since Bdellostoma differs from Myxine in the arrangement of its oblique muscles (Müller discovered that in the former the oblique muscles pass external to the slime glands), there is the possibility that the two myxinoids differ in the manner in which they secrete slime.

In the post-anal region of Myxine, the slime glands are surrounded by the striated muscle fibres of the $m$. transversus caudalis (Cole, I907, p. 750), which without question must be related to the expulsion of slime from the glands, for it surrounds them and is not related to any other structures.

My own silver and methylene-blue preparations of the slime glands of Myxine show that matters are more complicated than previous workers have supposed, for the slime glands are covered by a rich nerve plexus containing many cell bodies (Pl. I, figs. 4, 5). These cell bodies are in connexion with axons derived from the spinal nerves, which terminate upon them in pericellular endings (Pl. I, fig. 6) similar to those figured for the subcutaneous cells by Retzius.

Each slime gland (including the post-anal ones) is supplied by several thick axons, which branch repeatedly upon the surface of the gland to synapse with many neurons. On each gland there may be about 50 neurons, which appear to be either bipolar or unipolar, like those of the subcutaneous plexus. It is difficult to trace their axons, which stain poorly in my preparations, but some can be followed for a short distance, when they branch several times.

What is the probable function of this system of neurons? At one point, around the orifice of the slime gland, there are especial concentrations of neurons (P1. I, fig. 7) which are associated with small bundles of unstriated 
muscle fibres grouped around the base of the slime gland. These muscle fibres form a sphincter around the opening of the gland, and it seems probable that the neurons associated with them are motor, and, whatever the cause of the increase of pressure within the gland which expels the contents, the actual expulsion would appear to be controlled by the degree of contraction of these sphincter fibres, regulated by the groups of neurons close to them.

Such neurons are identical in form, and in their connexion with the central axons, to those found upon the body of the gland, so that it seems reasonable to regard the latter as also motor to smooth muscle fibres in the gland capsule, though such fibres are difficult to demonstrate with certainty. There are certain objections to this view (which would suggest that the increase of pressure within the gland is caused by the intrinsic smooth musculature of the capsule); the chief is perhaps that in the post-anal region the slime glands are surrounded by a strong striated muscle sheet which cannot but be regarded as involved in the expulsion of slime from the glands.

Perhaps the increase of pressure upon the gland, which (when the sphincter around its orifice relaxes) results in the production of slime, is produced both by the intrinsic smooth musculature of the capsule and by the striated oblique and transverse caudal muscles; but it is certainly curious that in the post-anal slime glands the capsular neurons are as abundant as they are in the pre-anal region. I would agree with Blomfield that it is necessary to point out that these are speculations, which require to be confirmed by physiological experiment before we can decide the exact manner in which the slime is produced by the animal, but what is clear is that the neurons of the capsular plexus, whether or not we are correct in supposing them to be motor to smooth muscle fibres, represent an important part of the autonomic nervous system of the animal which has not hitherto been observed. It would be interesting to know whether the central axons that synapse upon these neurons emerge from ventral or from dorsal roots, but whilst this would be an easy matter to determine by electrophysiological experiment (for the spinal roots in Myxine are readily accessible), I do not believe that it is possible to discover by histological examination.

The remarkably abundant neurons of the subcutaneous plexus which were discovered by Retzius (and which Langerhans (1873) observed in petromyzonts) are very like those of the slime-gland capsules (Pl. I, fig. 8). They lie as a rule in the nerve bundles beside the small blood vessels of the sub-cutis (they are never found in the connective tissue layer of the dermis), and are surrounded by pericapsular terminations of central axons. With the cells there are often visible satellite cells and nuclei, presumably similar to those found in the autonomic ganglia of higher forms. These satellite cells are different in appearance from the sheath cells and nuclei which are found along the nerve bundles. It is not possible to trace the axons of the neurons in my preparations, for they are lost amongst the branches of the central axons, some of 
which synapse upon them; like the capsular neurons of the slime glands it seems that they may be bipolar or unipolar. Similar neurons are found in petromyzonts, but in my preparations they are very much less abundant than in the subcutaneous plexus of Myxine. It is not very easy to understand what all these subcutaneous neurons may be doing, for a similar plexus is not found in any other chordate (the innervation of the skin of Acrania and of teleosts is very different). Retzius cautiously avoided any speculation as to their function. The resemblance of these neurons to those of the slime glands, and the probability that the latter system is but a specialization of the former, suggests that the system is likely to be motor, controlling smooth muscle fibres. Such fibres (which stain yellow after van Gieson, red after Azan) are found in the subcutaneous layers, mainly at the dorsal and ventral parts of this layer, and in the walls of the arterioles near which many of the cells lie. Exactly what these smooth muscle fibres of the subcutaneous layer may do is not known, but it appears to me likely that in some manner they are concerned with the regulation of the flow of venous blood through the extensive subcutaneous sinuses. Clearly, when the animal swims, blood will surge about in these sinuses (for, in effect, Myxine lies in a tube filled with venous blood whose wall is formed by the skin). Such a system must be extremely inefficient and liable to disorganization during violent movement by the animal. Whether or not the contraction of the smooth muscles of the subcutaneous layer does more than regulate the surging of the venous blood in the subcutaneous sinuses-i.e. whether it can produce a circulation in the quiescent animal-is a question for experiment.

The view taken of the subcutaneous plexus is not based upon any experimental evidence, and may well have to be abandoned when such evidence is forthcoming. It does seem, however, worth attempting to link the two very remarkable characters of the skin of Myxine (the venous sinuses and the subcutaneous neurons), and it would be very interesting to see whether the vasomotor role suggested here for the subcutaneous neurons can be supported by experimental evidence.

I am indebted to Dr D. B. Carlisle for his kindness in fixing hagfish for me at Kristineberg zoological station, and to Dr H. G. Vevers for assistance in the transport of living hagfish from the same source.

\section{SUMMARY}

Observations are described upon the innervation of striated muscles, the innervation of the slime glands, and the subcutaneous innervation in the hagfish, Myxine glutinosa L. It is shown that the two types of striated muscle fibre receive different types of motor innervation. Presumed sensory endings are described from above the striated muscle fibres of the ventral part of the body, and are similar to those endings near to the dorsal root ganglia which 
can be traced to their cells of origin within the ganglia. It is suggested that these endings are proprioceptive in function. Other endings within the outer edge of the myosepta are described, which may possibly also have a proprioceptive function. A rich plexus of neurons is described upon the capsule of the slime glands, and these neurons, like those of the subcutaneous plexus, receive pericellular terminations from the axons of central cells. It is suggested that they are motor to smooth muscle fibres, in the slime-gland plexus being related to the expulsion of slime (together with the action of striated muscle fibres), and in the subcutaneous plexus playing some role in the control of the venous blood in the subcutaneous sinuses.

\section{REFERENCES}

AdAm, H., 1960. Different types of body movement in the Hagfish, Myxine glutinosa L. Nature, Lond., Vol. 188, pp. 595-6.

ALLEN, W. F., I917. Distribution of the spinal nerves in Polistotrema and some special studies on the development of spinal nerves. F. comp. Neurol., Vol. 28, pp. 137-213.

ANDERSEN, P., JANSEN, J. \& LøYNING, Y., 1962. Myotomal musculature of the hagfish (Myxine glutinosa) investigated with intracellular electrodes. (In the Press.)

BARETS, A., I956. Les récepteurs intra-musculaires des nageoires chez les sélaciens. Arch. Anat. micr. Morph. exp., T. 45, pp. 254-60.

— I96I. Contribution à l'étude des systèmes moteurs 'lent' et 'rapide' du muscle lateral des téléostéens. Arch. Anat. micr. Morph. exp., T. 50, Suppl. I, pp. 92-I87.

Barker, D., 1958. The evolution of stretch receptors in vertebrates. Proc. Cent. Bicent. Congr. Biol., Singapore, pp. 53-7.

Blomfield, J. D., I882. The thread cells and epidermis of Myxine. Quart. F. micr. Sci., Vol. 22, pp. 355-6I.

Bone, Q., I963. Patterns of muscular innervation in lower chordates. Int. Rev. Neurobiol. (In the Press.)

BRANDT, W., 1922. Das Darmnervensystem von Myxine glutinosa. Z. Anat. EntwGesch., Bd. 65, pp. 284-292.

CAVAlIÉ, M., I902. Sur les terminaisons nerveuses motrices et sensitives dans les muscles striés, chez la Torpille (Torpedo marmorata). C.R. Soc. Biol., Paris, T. 54, pp. 1279-80.

Cole, F. J., 1907. A monograph on the general morphology of the Myxinoid fishes, based on a study of Myxine. Part II. The anatomy of the muscles. Trans. roy. Soc. Edinb., Vol. 45, pp. 683-757.

DAvID, G. B., I955. The effect of eliminating shrinkage artefacts on degenerative changes seen in c.n.s. material. Excerpta med. Amst. neurol., Vol. 8, pp. 777-8.

DogIEL, A. S., I898. Die sensiblen Nervenendigungen im Herzen und in den Blutgefässen der Säugethiere. Arch. mikr. anat., Bd. 52, pp. 44-70.

FäNGE, R. \& JohNeLS, A., 1959. An autonomic nerve plexus control of the gall bladder in Myxine. Acta zool., Stockh., Vol. 39, pp. I-8.

FERRY, J. D., 194I. A fibrous protein from the slime of the hagfish. F. biol. Chem., Vol. 138, pp. 263-8.

FESSARD, A. \& SAND, A., I937. Stretch receptors in the muscles of fishes. F. exp. Biol., Vol. I4, pp. 383-404.

Giacomini, E., I898. Sulla maniera onde i nervi si terminano nei miocommi e nelle estremità delle fibre muscolari dei miomeri nei Teleostei. Atti Accad. Fisiocr. Siena, Vol. 10, pp. 37 I. 
GRENACHER, H., I867. Beiträge zur näheren Kenntniss der Muskulatur der Cyclostomen und Leptocardier. Z. wiss. Zool., Bd. 17, p. 577.

Healey, E. G., 1957. The Nervous System. In The Physiology of Fishes, ed. M. E. Brown, Vol. 2, pp. I-II9. New York: Academic Press.

JANSEN, J. \& ANDERSEN, P., I960. Observations on slow and fast muscle fibers in the hagfish (Myxine glutinosa). Acta physiol. scand., Vol. 50, Suppl. 175, pp. 76-7.

JoHNELS, A. G., I956. On the peripheral autonomic nervous system of the trunk region of Lampetra planeri. Acta zool., Stockh., Vol. 37, pp. 25I-6.

JoHnston, J. B., I908. On the significance of the caliber of the parts of the neuron in vertebrates. F. comp. Neurol., Vol. 18, pp. 609-18.

KATZ, B., I96I. The terminations of the afferent nerve fibre in the muscle spindle of the frog. Phil. Trans., B, Vol. 243, pp. 22I-40.

Kolmer, W., I905. Zur Kenntnis der Rückenmarks von Ammocoetes. Anat. Hefte, Bd. 29, Hft. 2, pp. I63-2I4.

Langerhans, P., I873. Untersuchungen über Petromyzon planery. Verh. naturf. Ges. Freiburg, Bd. 6, pp. I-II5.

Lissman, H. W., I $946 a$. The neurological basis of the locomotory rhythm in the spinal dogfish (Scyllium canicula, Acanthias vulgaris). I. Reflex behaviour. F. exp. Biol., Vol. 23, pp. I43-I6I.

- 1946 $b$. The neurological basis of the locomotory rhythm in the spinal dogfish (Scyllium canicula, Acanthias vulgaris). II. The effect of de-afferentation. F. exp. Biol., Vol. 23, pp. I62-76.

MACKAY, B., MUIR, A. R. \& Peters, A., I960. Observations on the terminal innervation of segmental muscle fibres in Amphibia. Acta anat., Vol. 40, pp. I-I2.

Martino, L., 1958. Sui recettori del senso muscolare nel muscolo vocale. (A proposito dei corpi sferoidi di Terio.) Arch. zool. (ital.), Torino, Vol. 43, pp. 7I-84.

MAURER, F., 1894. Die Elemente der Rumpfmuskulatur bei Cyclostomen und höheren Wirbeltieren. Morph. F., Bd. 21, pp. 473-6I9.

MÜLleR, J., I836. Vergleichende Anatomie der Myxinoiden, der Cyclostomen mit durchbohrtem Gaumen. Pt. I. Osteologie und Myologie. Abh. preuss. Akad. Wiss., 1834, pp. 65-340.

Newby, W. W., 1946. The slime glands and thread cells of the hagfish, Polistotrema stouti. F. Morph., Vol. 78, pp. 397-409.

PALMGREN, A., I948. A rapid method for selective silver staining of nerve fibres and nerve endings in mounted paraffin sections. Acta zool., Stockh., Vol. 29, pp. $377-92$.

- 195I. A method for silver staining nerve fibres in very thick sections and in suitable whole preparations. Acta zool, Stockh., Vol. 32, pp. I-IO.

Peters, A. \& MACKAY, B., I96r. The structure and innervation of the myotomes of the lamprey. F. Anat., Lond., Vol. 95, pp. 575-85.

PoloumORDWINOFF, D., I898. Recherches sur les terminaisons nerveuses sensitives dans les muscles striés volontaires. Trav. Lab. Soc. sci. Arcachon, Vol. 3, pp. 73-9.

RetziUs, G., I890. Über die Ganglienzellen der Cerebrospinalganglien und über subcutane Ganglienzellen bei Myxine glutinosa. Biol. Untersuch., N.F., Bd. I, pp. $97-9$.

— I892. Zur Kenntniss der motorischen Nervendigungen. Biol. Untersuch., N.F., Bd. 3, pp. 4I-52.

Steedman, H. F., I957. Polyester wax. A new ribboning embedding medium for histology. Nature, Lond., Vol. 179, p. I345.

Ten Cate, J., 1935. Physiologie des Zentralnervensystems der Fische. Ergebn. Biol., Bd. II, pp. 335-409. 

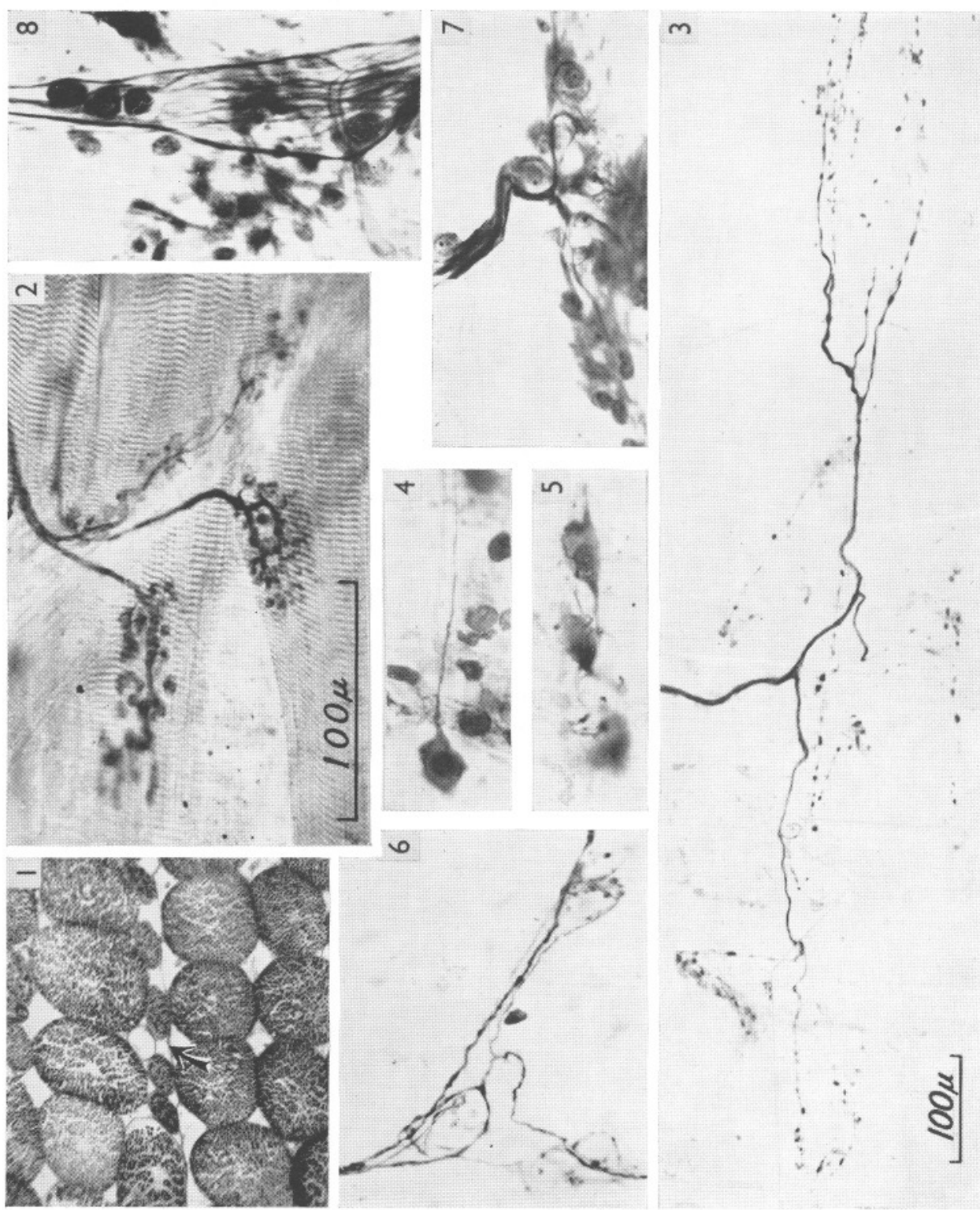

(Facing p. 47) 


\section{EXPLANATION OF PLATE I}

Fig. I. Cross-section of a part of the parietal muscle, showing the smaller B fibres aligned along the bottom of the muscle unit between rows of larger A fibres. The arrow indicates the connective tissue sheet separating the two muscle units. Iron haematoxylin.

Fig. 2. End-formations of the large-axon system upon A-type muscle fibres from the rectus muscle. Methylene blue whole-mount preparation.

Fig. 3. Sensory ending from inner surface of parietal muscle. This ending can be traced back to its cell of origin within the dorsal root ganglion. Methylene blue whole-mount preparation.

Fig. 4. Neuron from slime-gland plexus, axon to right. Methylene blue whole-mount preparation.

Fig. 5. Two neurons from the same plexus, the synapsing fibre from a central cell (?) is faintly visible upon the right-hand cell. Methylene blue whole-mount preparation.

Fig. 6. Axons of central cells within the slime-gland plexus showing pericellular baskets around the (unstained) neurons of the plexus. Methylene blue whole-mount preparation.

Fig. 7. Central axons passing to groups of neurons around the orifice of the slime gland. Palmgren's silver method, $28 \mu$ polyester wax section.

Fig. 8. Neurons of the subcutaneous plexus associated with a bundle of nerve fibres crossing a small vessel. Palmgren's silver method, $28 \mu$ polyester wax section.

Figs. I and 3 to same scale, all others to scale of fig. 2. 